revista ANTHROPOLÓGICAS

Ano 23, 30(2): 63-90, 2019

\title{
As Vidas dos Artefatos Ameríndios Amazônicos numa Coleção Etnográfica Italiana
}

Paride Bollettin ${ }^{\mathrm{a}}$

Este trabalho apresenta os artefatos Ameríndios amazônicos da Coleção Etnográfica do Centro Studi Americanistici 'Circolo Amerindiano', na Itália. Uma das mais importantes coleções etnográficas dedicadas aos povos Ameríndios, esta possui um rico acervo de artefatos Ameríndios oriundos de todo o continente americano. Aqui serão detalhados os objetos que compõem a parte amazônica dessa Coleção. O intento do trabalho é mostrar como tais artefatos possam ser observados não como simples objetos inertes e passivos, mas sim como sujeitos ativos de uma continua produção de diferenças que redefine os outros sujeitos envolvidos nos encontros museais. Dessa forma, os artefatos permitem a emergência da agência Ameríndia mesmo quando os Ameríndios não estão diretamente engajados no percurso expositivo.

Circolo Amerindiano, Povos indígenas, Brasil, Coleções etnográficas, Objetos.

Andando pelas ruas de pedras de uma cidade medieval italiana, uma das muito famosas por suas arquiteturas medievais, renascentistas e barrocas, o visitante sente-se mergulhado num passado que se torna constantemente presente e revivido através da experiência direta. Estes passados, medievais, renascentistas e barrocos, tornados presentes, levam a incorporar o movimento de percepção do tempo

a Doutor em Antropologia pela Universidade de Perúgia (Itália). Professor no Departamento de Antropologia (UFBA). Email: paride_bollettin@msn.com. 
e dos deslocamentos cognitivos que tais arquiteturas estimulam. $\mathrm{O}$ distanciamento temporal é anulado na experiência física de encontro com as arquiteturas, no contato direto e presencial com algo produzido por pessoas afastadas diacronicamente. Estas arquiteturas produzem uma transformação na percepção do fluir do tempo, no devir de uma colisão que subsome a distancia num processo de encontro nos quais os atores são reciprocamente redefinidos. Longe de ser frias e inertes pedras, as arquiteturas agem enquanto termos de uma relação que reconstrói, redefinindo-os, os próprios sujeitos envolvidos nesses encontros.

Uma dessas cidades, localizada no 'coração verde da Itália', é a cidade de Perugia. Aqui, andando pelas ruas de pedra do centro histórico, é possível encontrar uma placa inesperada: 'Centro Studi Americanistici'. No térreo de um prédio, uma imagem estilizada da cabeça de Pakal K'inich Janaab' observa com olhar intenso. Trata-se de um outro encontro: o rei Maya da cidade de Palenque acolhe o visitante na entrada da sede desse centro de pesquisa interdisciplinar dedicado ao estudo dos povos Ameríndios do continente americano. Ele introduz a outra transformação, diacrônica e sincrônica ao mesmo tempo. Vivido no sétimo século na Mesoamérica, este rei foi o responsável pela edificação do templo de B'olon Yej Te’ Naah, o Tempo das Inscrições, a maior das pirâmides de degraus pré-colombianas do povo Maya. Através do olhar do rei, o visitante perpassa a fronteira temporal entre o presente do vivido e o presente da edificação do templo. Mas este olhar permite de perpassar também a fronteira geográfica que separa o mundo perugino do mundo Ameríndio. Um duplo movimento que junta os atores em novos encontros. $\mathrm{O}$ passado e o presente, assim como o longe e o perto, são fundidos em uma experiência imediata e incorporada. $\mathrm{O}$ rei, assim como as pedras das arquiteturas medievais, renascentistas e barrocas, não é simplesmente um logotipo, mas sim um ator que libera possibilidades virtuais de novos encontros.

Essas premissas nos permitem situar a discussão desse texto. De que forma os artefatos Ameríndios habitantes da coleção etnográfica 
do Centro Studi Americanistici 'Circolo Amerindiano' propiciam um encontro entre os visitantes e os povos que os produziram? Para nos aproximar dessa discussão, precisamos repensar o estatuto da fronteira entre 'sujeitos' e 'objetos', libertando o potencial transformador que estes artefatos incorporam. Como as pedras da cidade de Perugia e a cabeça de Pakal K'inich Janaab', estes objetos redefinem o posicionamento dos envolvidos no encontro: andarilhos, guias e artefatos - e com eles as vitrines, as memorias, as instituições que financiam o Centro Studi, os pesquisadores que formaram as coleções, etc. - juntam-se num movimento de redefinição reciproca. Os artefatos não 'são', eles assumem posições agentivas fluidas e flexíveis, eles veiculam agentividades Ameríndias para além dos limites diacrônicos e sincrônicos, mas eles também agem enquanto sujeitos autônomos, parcialmente desvinculados dos seus contextos de fabricação, numa posição na qual sua biografia individual os situou.

Para introduzir essa discussão, iremos seguir um caminho que pode levar a diferentes encontros. No começo ilustraremos a Coleção Etnográfica do Centro Studi Americanistici 'Circolo Amerindiano', observando algumas experiências de encontro que produzem-se nesse ambiente. Em seguida, será apresentado um panorama das discussões contemporâneas sobre as agentividades dos objetos, dos artefatos e mais em geral do 'material'. Enfim, refletiremos sobre como os objetos Ameríndios ativam múltiplas agentividades, tornando efetivos os encontros com as experiências Ameríndias apesar das distancias diacrônicas e sincrônicas. Devido as limitações de espaço de um artigo, apesar da Coleção Etnográfica ser composta por artefatos arqueológicos e etnográficos oriundos de todo o continente americano, da região subártica à Terra do Fogo, passando pelas planícies do hemisfério norte, Mesoamérica, montanhas da Cordilheira do Andes e pelas Terras Baixas do hemisfério Sul, focaremos aqui somente nos objetos Amazônicos. Todavia, esperamos que as sugestões aqui apresentadas possam estimular o reconhecimento de movimentos similares também nos encontros com os artefatos que nasceram em outras regiões. 


\section{O centro de documentação e pesquisa do centro studi americanistici 'circolo amerindiano'}

O Centro Studi Americanistici 'Circolo Amerindiano', é uma associação que tem como finalidade a pesquisa, a divulgação e a defesa dos povos e das culturas que habitam ou habitaram o continente americano. Foi fundado em 1977 na cidade de Perugia, por um grupo de apaixonados, acadêmicos ou não, do tema da americanistica. Essa definição 'americanistica' indica a ausência, nos interesses do Centro, de limites geográficos, sendo incluído todo o território continental, do Estreito de Bering à Terra do Fogo, de limites temporais, do primeiro povoamento aos dias atuais, e de limites disciplinares, abrangendo disciplinas como antropologia, arqueologia, historia, artes, politicas, linguística, etc. A filosofia que embasa as atividades do Centro Studi é que a pesquisa, enquanto modalidade de conhecimento, deva ser associada à cooperação com os povos Ameríndios, através de projetos de colaboração, assim como através da divulgação da realidade histórica e contemporânea desses povos para o publico não especializado. Nesse sentido, parece-me equivocada a associação de 'americanistica' com 'orientalismo' (Machado \& Silva 2010), pois este ultimo remete a uma autoidentificação do Ocidente frente a um Oriente idealizado (Said 1978), sendo que nessa versão da 'americanistica' realiza-se uma pesquisa-ação que leva em conta primariamente as realidades locais do continente americano enquanto ponto de partida e de chegada das diferentes atividades realizada pelo Centro Studi Americanistici.

Em 2005, o Centro Studi inaugurou uma segunda sede na cidade de Salerno, no sul da Itália, e em 2007 foi se constituindo um grupo de sócios na cidade de Padova, no norte do País. Na cidade de Perugia, contudo, o Centro Studi mantém sua sede principal, assim como nessa cidade é também organizado o Congresso Internacional de Americanistica que todo ano junta pesquisadores de vários países para discutir diferentes temas. Os espaços da sede do Centro Studi são oferecidos pela Prefeitura da cidade de Perugia, em uso gratuito, reconhecendo assim a importância educativa que as atividades do 
mesmo desempenham na região. Estas, além do mencionado Congresso Internacional, incluem a publicação da Revista Thule e de livros especializados, pesquisas em vários países, projetos de cooperação internacional, atividades didáticas nas escolas e de divulgação para um amplo publico na região. No contexto de atividades, o Centro Studi criou um Centro de Documentação e Pesquisa em 2004, quando deslocou-se para a atual sede (Marchetti \& Nicolardi 2007).

Este último é constituído por um acervo de mais de trinta mil livros, quatrocentos títulos de revistas, milhares de imagens e vídeos e centenas de artefatos etnográficos, compondo um dos maiores arquivos em nível italiano sobre o tema. Os materiais são disponíveis ao publico graças às contribuições de diferentes órgãos públicos e privados: a Consulta para a Imigração da Região Umbria apoia economicamente o Centro Studi a mais de vinte anos, a Fundação da Cassa di Risparmio, em 2003, financiou a aquisição de materiais para a exposição etnográfica e o Ministério dos Bens e Atividades Culturais, através da Secretaria para os Bens Bibliográficos oferece um apoio financeiro.

Em 2004, com a inauguração da atual sede e do Centro de Documentação e Pesquisa, a biblioteca do Centro Studi adquiriu duas importantes coleções, uma da Fundação Lelio Basso e a outra do pesquisador Rodolfo Calpini (Marchetti \& Nicolardi 2007). Em 2010, mais duas coleções foram doadas o Centro Studi: uma do Instituto Latino Americano e a outra do pesquisador Roberto Giammanco. Em 2015, também a coleção particular do pesquisador Igino Gatti confluiu na biblioteca. Outras, como aquela do Professor Gerardo Bamonte, estão em fase de aquisição. Todas estas se juntaram ao acervo já constituído e que é constantemente incrementado por doações de pesquisadores individuais e redes de trocas de publicações (algumas dessas, para mencionar exemplos brasileiros, envolvem o ISA-Instituto Socioambiental e o Iepe-Instituto de Pesquisa e Formação Indígena). A biblioteca tornou-se publica, ou seja inserida no circuito das bibliotecas municipais em 2007 e em 2017 foi intitulada Biblioteca de Americanistica Tullio Seppilli. 
Além da biblioteca, o Centro Studi possui um Centro de Documentação Áudio-Visual, dedicado à memoria do pesquisador Daniele Fava. Nesse acervo são acolhidos materiais fotográficos, fílmicos e sonoros coletados ao longo de mais de trinta anos pelos sócios ou adquiridos através de doações por parte de instituições. Estes materiais compreendem tanto filmes de ficção, documentários etnográficos ou arqueológicos, como também materiais de pesquisa, gravações de palestras, etc. Ademais, no Centro de Documentação Audio-Visual estão guardados os quase trezentos painéis das exposições temporárias, sobre as quais voltaremos em breve. Em 2008 começou o projeto 'As Américas em Digital', o qual visa a digitalização desses materiais, com a finalidade de torna-los mais accessíveis para o publico e de garantir sua preservação. Este projeto foi possivel através de um financiamento do Centro de Serviços ao Voluntariado da Prefeitura da cidade de Perugia.

Como mencionado, as atividades do Centro de Documentação e Pesquisa do Centro Studi Americanistici incluem um percurso expositivo itinerante, composto por 653 ampliações fotográficas montadas em 297 painéis rígidos em material plástico. Esse percurso expositivo é pensado em formato modular, podendo ser organizado por áreas temáticas ou por áreas geográficas dependendo da finalidade expositiva. A exposição foi apresentada pela primeira vez em 1980 ao longo da Semana Latino-americana que aconteceu na cidade de Gubbio, também na região da Umbria. A primeira constituição do percurso expositivo era voltada à apresentação de um itinerário histórico e etnográfico dos povos e das culturas das Américas e intitulada 'Teocuicatl: o canto sagrado'. Ao longo dos anos, esse percurso foi acrescentando módulos com temas específicos: 'Homens de mais' apresenta a historia e a cultura dos povos mesoamericanos; 'Hoke hey', dos povos norte-americanos; 'America Latina: um continente em suspenso', a historia da colonização e da formação indentitária dessa parte do continente; 'Notas de América', a historia das musicas indígenas e populares; 'Os signos do universo', a ciência, a filosofia e a escrita mesoamericanas; 
'Pacha kunturpa', os povos da região andina; 'Homens e florestas', os povos amazônicos; 'Males do corpo, males da alma', xamanismo e praticas de cura dos Ameríndios; 'Os nomes de Deus', as múltiplas religiosidades Ameríndias antes e depois da chegada do cristianismo; 'Terra de mais', os povos campesinos da América Central; 'Terra e Liberdade', a historia da revolução mexicana. Estes percursos expositivos são apresentados com frequência regular ao publico nos mais diferentes contextos, como outros museus, escolas, centros comunitários ou espaços publico, etc. (Marchetti \& Nicolardi 2007).

Ademais, outras exposições temporárias, de cunho mais especializado, são organizadas com os materiais do Centro de Documentação Áudio-Visual. Um exemplo dessas últimas é a exposição fotográfica 'A infância Mebengokré-Xikrin', que foi apresentada em 2007 no âmbito do XXIX Congresso Internacional de Americanistica nos espaços do Palácio dos Priores da cidade de Perugia. Este percurso visava apresentar em 20 painéis fotográficos acompanhados de descrições etnográficas as fases de crescimento social dos indivíduos entre esse povo Ameríndio. Outro exemplo é a exposição etnográfica 'A Amazônia em Perugia' que foi montada em 2011 no Prédio do Governo no âmbito do XXXIII Congresso Internacional de Americanistica. Neste ultimo caso, além dos painéis fotográficos, foram incluídos no percurso expositivo vários artefatos amazônicos da Coleção Etnográfica do Centro Studi, sobre a qual nos determos no próximo paragrafo.

\section{A coleção etnográfica}

Essa coleção surge oficialmente em 1991, quando a exposição temporária 'Teocuicatl: o canto sagrado' foi organizada na cidade de Terni, também situada na região da Umbria. A partir desse evento, o Centro Studi Americanistici decidiu de reunir num único espaço os artefatos etnográficos coletados pelos sócios ao longo de suas viagens nas Américas. Vem assim a se constituir o primeiro acervo, ainda na primeira sede. Os artefatos são organizados seguindo uma divisão por marco-áreas geográficas: Polar, Norteamericana, Mesoamericana, Caribenha, 
andina, Amazônica, Litoral Atlântico, Cone Sul. Estas áreas são, por sua vez, subdivididas em áreas e regiões. Paralelamente, cruza-se com esse critério geográfico também outros critérios temático e temporal.

O núcleo inicial da coleção vai progressivamente incorporando um significativo numero de artefatos das áreas andina, amazônica e tropical venezuelana, sobretudo pelos aportes do arqueólogo Mario Polia e dos etnólogos Gerardo Bamonte e Miguel Angel Menéndez, além dos arquitetos Leszek Zawisza e Chiara Cipiciani. Em 2002 foram adquiridos mais de duzentos artefatos da coleção pessoal da antropóloga Nina Borruso, principalmente oriundos da região centromeridional do Mexico, e de mais de sessenta artefatos da coleção pessoal do antropólogo Gerardo Bamonte, principalmente amazônicos. Ambas essas aquisições foram financiadas pela Fundação da Cassa di Risparmio de Perugia, um banco privado que colabora ativamente com as atividades do Centro Studi Americanistici (Marchetti \& Nicolardi 2007). Outros sócios também contribuíram e contribuem com continuas doações de artefatos, de forma que a coleção assume a forma de um conjunto em processo. Não se trata de um acervo fechado e estático, mas de uma continua reformulação e ressemantização do conjunto a cada nova aquisição. Importante é evidenciar como varias das peças presentes na Coleção Etnográfica foram doadas expressamente com a finalidade de ser nesta incorporadas por membros de diferentes povos indígenas. Este é o caso, por exemplo, de alguns artefatos Mebengokré (povo Gê do Brasil central), os quais foram entregues a um sócio do Centro Studi para que os levasse até a Itália e permitisse que 'as pessoas de lá conheçam nossa cultura'. Outros artefatos foram doados à Coleção Etnográfica por parte de representantes de povos Ameríndios que participaram no anual Congresso Internacional de Americanistica, ou em outros eventos organizados pelo Centro Studi Americanistici.

Em 2004, quando da inauguração da atual sede do Centro Studi Americanistici, a Coleção Etnográfica foi organizada na sua instalação atual. Em 2009 a mesma foi dedicada à memoria de Gerardo Bamon- 
te, ideólogo e promotor da mesma, incansável divulgador do conhecimento sobre e sensibilizador para as lutas dos povos Ameríndios para o amplo publico. Em 2019, a Prefeitura da cidade de Perugia destinou um novo espaço expositivo para uma nova instalação do percurso expositivo da Coleção Etnográfica, que garantirá uma maior visibilidade para com o publico e tornará possível a implementação de novas atividades didáticas com as escolas. A abertura desse novo espaço, com a conseguinte transferência da Coleção Etnográfica é previsto para o final de 2020. Concomitantemente com essa nova instalação, está prevista também a realização de um percurso virtual de visita, que permita o acesso à Coleção Etnográfica também por parte de um publico impossibilitado a viajar fisicamente até Perugia. Nesse texto, todavia, iremos descrever a atual composição, tendo em vista que importantes novas ações serão realizadas num futuro próximo.

Outra ressalva importante a ser feita concerne os materiais arqueológicos. Um dos pressupostos do Centro Studi Americanistici sempre foi um cuidado a não aceitar artefatos não reproduzíveis. As únicas exceções sendo aquele que já se encontrem afora do continente americano e que corram o perigo de ser deterioradas ou dispersas. Nessa direção a Coleção Etnográfica aceita doações somente de artefatos etnográficos de uso comum e reprodutíveis, e de reproduções arqueológicas. Entre essas reproduções de objetos arqueológicos destacam-se as reproduções de artefatos norte-americanos de autoria de Sergio Susani e mesoamericanos do Taller de Reproducciones do Instituto Nacional de Antropología e Historia de Cidade do México. Outros artefatos significativos presentes na Coleção Etnográfica, e que detêm um importante uso didático são as reproduções de cenas de caça e de vida cotidiana dos povos indígenas norte-americanos e dos Yanomami realizadas por Antonio Masetti. Estes incluem uma reprodução de uma maloca Yanomami com diferentes cenas de vida cotidiana.

O percurso expositivo atual retoma a estrutura do original organizado na sede anterior, com a subdivisão por áreas geográficas e dentro dessas por eixos temáticos e cronológicos. Os espaços são divididos 
em três salas, sendo a primeira dedicada aos povos das regiões circumpolar, norte-americana e mesoamericana pré-colombiana; a segunda sala aos povos centro-americanos contemporâneos; e a terceira aos povos andinos, amazônicos e do Cone Sul. Os artefatos são apresentados em prateleira de vidro temperado fechadas ou em espaços abertos dependendo de sua resistência ao clima e ao manuseio por parte dos visitantes. Assim, por exemplo, coroas plumarias amazônicas são guardadas em expositores dedicados, de forma a preservar o material orgânico que as compõem, enquanto instrumentos musicais de percussão andinos são colocados a disposição do publico que pode ter experiência das diferentes texturas dos materiais dos quais são compostos.

Nesse panorama, assumem especial interesse para nosso argumento os artefatos amazônicos habitantes dessa coleção. Como mencionado acima, o núcleo inicial desse acervo foi constituído pelos etnólogos Gerardo Bamonte e Miguel Angel Menéndez. Estes incluíam artefatos oriundos do alto Rio Negro, do rio Xingu, do Chaco e, em menor medida, de outras áreas. $\mathrm{O}$ núcleo da Coleção Etnográfica, portanto, já visava apresentar um panorama da diversidade dos povos que habitam a Amazônia, desconstruindo o imaginário tão enraizado no senso comum do mundo ocidental que pensa aos povos indígenas enquanto sujeitos indiferenciados. Ademais, a presença de artefatos mais 'exóticos', como cocares plumários, e de outros produzidos com materiais industrializados, como por exemplo pulseiras de miçangas, permitia de apresentar esses povos 'da floresta' (como o titulo da exposição temporária mencionada acima) em sua dinamicidade histórica, quebrando o estereotipo, esse também enraizado no senso comum ocidental, que vê esses povos enquanto parados no tempo. Entende-se assim como a experiência etnográfica, enquanto orientadora da experiência expositiva desses artefatos, permite de sugerir novos encontros que visam reformular as posições reciprocas dos sujeitos envolvidos, sejam esses os próprios artefatos, os visitantes e os povos Ameríndios. Cabe agora nos interrogar sobre como esses encontros desencadeiam tais processos. 


\section{As vidas de uma borduna}

Em 2005, em ocasião de uma viagem para pesquisa de campo entre os Mebengokré da Terra Indígena Trincheira-Bacajá, situada ao longo do curso do rio Bacajá, recebi, no dia anterior a minha despedida, uma borduna, ko, de presente por parte de Tedjore, um dos homens mais idosos da aldeia Mrõtidjam, onde tinha passado cerca de três meses. Ao presentear-me com a borduna, ele foi recomendando que eu não me esquecesse deles e que voltasse o quanto antes para encontrá-los novamente.

A borduna que Tedjore me entregou é um pau de madeira de formato cilindrico com um comprimento de aproximadamente um metro e meio, com o cabo ligeiramente afinado e ornado com estrias paralelas cavadas em baixo-relevo, além de ter duas pontas nas extremidades. Segundo a classificação de Berta Ribeiro, pode ser descrita como "circular semi-estriada" (Ribeiro 1988:219). Ao longo da última semana de permanência na aldeia, com frequência eu sentava do lado dele para conversar sobre assuntos variados, enquanto ele cortou e alisou o artefato. No final, pouco antes de me entregar, acrescentou um fio de algodão findado em franja tinto com urucum no cinto de separação entre o cabo e o corpo da arma.

A borduna, na experiência Mebengokré, constitui um elemento definidor da subjetividade do seu portador, juntamente com outros elementos incluídos na categoria kukradja (Fisher 1991; Cohn 2005; Lea 2012; Bollettin 2019). No passado era utilizada enquanto instrumento de guerra e inúmeros relatos etnográfico apresentam o uso dessa arma para fins bélicos, seja entre os Mebengokré-Xikrin do Rio Bacajá, seja entre outros grupos Mebengokré. Ademais a borduna era utilizada para atividades venatórias, servindo para caçar tanto animais de grande porte, como a anta, quanto animais menores, como a cotia. Ao longo das minhas permanências entre os Mebengokré, de 2005 até hoje, ela foi utilizada para caçar em esporádicas ocasiões, quando cartuchos para os fuzis não eram disponíveis. Em todos os casos que testemunhei de uso da borduna na caça, as presas foram queixadas, 
e nunca a vi ser usada com outros animais. A borduna é largamente utilizada também quando da realização dos vários rituais que marcam a cotidianidade Mebengokré na aldeia Mrõtidjam. Os mebenghete, os anciões, levam suas bordunas nas danças segurando-as com a mão e apoiando-as no ombro. Eles as levam no ngáb, a Cada dos Homens também quando é realizada alguma reunião dedicada a assuntos especialmente relevantes, e nesses momentos costumam brandi-las agitando-as no ar como forma de ênfase ao longo dos discursos proferidos. Outro uso evidente da borduna é sua presença constante quando os Mebengokré reúnem-se com os kuben, os 'brancos'. É uma presença marcante quando eles precisam reivindicar o cumprimento de acordos, a melhoria dos atendimentos de saúde e de educação, ou a defesa de seus direitos. Fica evidente, assim, como a borduna constitui um objeto carregado de inúmeras vidas: a o lado do caçador, do guerreiro, do orador, etc. A borduna perpassa assim a identidade masculina Mebengokré em níveis variados, individual e coletivo.

Depois da minha volta para Itália e ter convivido com a borduna com a qual foi presenteado em minha casa por alguns meses, resolvi cede-la em usufruto ao Centro Studi Americanistici para que pudesse ser incorporada no acervo da Coleção Etnografica e assim incluída no percurso expositivo. Para que o Centro Studi Americanistici aceitasse de incluir a borduna na Coleção Etnográfica, fui demandado de elaborar uma ficha catalográfica apresentando informações sobre o artefato e sua trajetória. Essa ficha incluía informações quais: o nome na língua original, o nome em italiano, a área geográfica de origem, além de subárea e região, o povo que a produziu e o nome do artesão, o período histórico de fabricação e de aquisição, as dimensões, o material de fabricação, as funções originais e uma descrição detalhada do significado do artefato no contexto de origem. Interessantemente, essas informações incluem tanto dados sobre a fabricação, quanto elementos de seu significado e usos originais. Essa demanda me foi, na época, explicada enquanto uma necessidade para que tais informações pudessem ser utilizadas no momento das visitas à Coleção 
Etnográfica. A principal preocupação sendo a possibilidade de contextualizar adequadamente e corretamente os artefatos em seus contextos quando apresentados ao publico.

A borduna foi enfim incluída no acervo da Coleção Etnográfica. Atualmente ela se encontra exposta pendurada numa das paredes da terceira sala expositiva, dedicada aos povos andinos e amazônicos. Ela se encontra lado a lado com um cocar Krokotire, o maior dos cocares Mebengokré, feito de plumas de cauda de arara azul amarradas com fio de algodão em um suporte semi-circular de madeira, que foi adquirido por outro sócio do Centro Studi Americanistici em uma loja de artesanato indígena. Este último é guardado em um quadro com moldura de madeira e vidro, enquanto a borduna é exposta sem contentor. Ao lado desses dois artefatos encontra-se um expositor de vidro de um metro e meio de altura, um metro e meio de comprimento e 40 centímetros de profundidade. Neste são expostos diferentes artefatos Ameríndios: cocares de menores dimensões da região do Xingu e do Rio Negro, bancos xamanicos Ticuna, etc. Trata-se de um expositor dedicado à apresentar os artefatos de uso 'ritual', sendo que outro expositores são utilizados para aqueles, por exemplo, de uso 'doméstico'.

Ela é apresentada ao publico através de uma descrição de seus múltiplos usos: bélico, venatório e ritual. Ademais é descrito como ela contribui, juntamente com outros elementos, materiais a imateriais, a definir a subjetividade de seu portador, sendo um agente produtor de diferenças individuais e coletivas. Assim ela permite de introduzir $\mathrm{o}$ visitante à experiência do povo Mebengokré em suas múltiplas facetas. A associação espacial com outros artefatos permite também de conecta-la com estes no espaço da Coleção Etnográfica. A organização espacial vem a se constituir assim como um instrumento cognitivo que leva o visitante a andentrar-se no denso universo relacional dos artefatos Mebengokré. Ela apresenta, porém, outro elemento qualificante no contexto da exposição. Tratando-se de um artefato resistente, pode ser manuseado pelo visitante, obviamente com a supervisão dos 
guias. O contato físico produz assim a possibilidade de 'incorporar' suas potencialidades pelo visitante, produzindo outro encontro e com este uma redefinição reciproca. A descrição de seu uso 'político', ademais, permite de levar o visitante a se aproximar dos desafios que os Mebengokré e os outros povos indígenas enfrentam e enfrentaram no contexto das relações com os não-indígenas nos dias atuais e no passado.

Observa-se, assim, como as múltiplas vidas da borduna nos coletivo Mebengokré permitem de propiciar ao visitante da Coleção Etnográfica múltiplos encontros com tais experiências. A biografia especifica da borduna exposta, artefato produzido especificadamente para presentear o visitante não-indígena, não anula seu potencial de propiciar tais encontros. Pelo contrario, permite de situar a própria experiência etnográfica especifica que permitiu à borduna de viajar até a Itália e de ser incluída na Coleção Etnográfica enquanto elemento de mobilidade das relações dos Mebengokré com seus interlocutores e seus artefatos. Permite, com isso, de multiplicar as redes relacionais dos atores envolvidos: Mebengokré, etnólogo, artefato visitante da exposição, etc. Obviamente, tais potencialidades não são exclusivas dessa borduna, mas poderiam ser mapeadas também nos outros objetos Ameríndios hospedados na Coleção Etnográfica. Vale a pena, agora, enumerar quais são estes.

\section{Os artefatos ameríndios amazônicos na coleção etnográfica}

Como mencionado acima, a Coleção Etnográfica não é um conjunto fechado e estático, mas sim um corpus em constante movimento de inclusão e transformação de novos elementos. $O$ mesmo vale inclusive para a parte dedicada as populações Amerindias amazônicas. Os artefatos têm diferentes origens, foram trazidos para a Coleção Etnográfica em diferentes momentos, e são expostos com diferentes modalidades expositivas. Todavia, é importante apresentar tais artefatos, para permitir de mostrar a variedade dos mesmos. Outros são constantemente incorporados ao percurso expositivo, alguns são reti- 
rados, portanto a lista abaixo não deve ser considerada, mais uma vez, exaustiva e definitiva. Como pode-se observar na listagem, não são todos os artefatos que são completamente identificados, sendo que os adquiridos incialmente não tiveram uma catalogação aperfeiçoada.

Tabela: Os artefatos Ameríndios amazônicos na Coleção Etnográfica do Centro Studi Americanistici. São especificados: tipo de artefato, região de origem, povo que o fabricou e época.

\begin{tabular}{|c|c|c|c|c|}
\hline Artefato & $\begin{array}{c}\text { Subárea } \\
\text { geográfica }\end{array}$ & Região & Povo & Época \\
\hline Cuia & Brasil central & Xingu & Waurá & $\begin{array}{l}\text { Contempo- } \\
\text { râneo }\end{array}$ \\
\hline $\begin{array}{l}\text { Colar de } \\
\text { fragmentos de } \\
\text { casca de coco }\end{array}$ & Brasil central & Xingu & Kenzabi & $\begin{array}{l}\text { Contempo- } \\
\text { râneo }\end{array}$ \\
\hline Boneca & Brasil central & Araguaia & Karajá & $\begin{array}{l}\text { Contempo- } \\
\text { râneo }\end{array}$ \\
\hline $\begin{array}{l}\text { Cesto de } \\
\text { upó. }\end{array}$ & $\begin{array}{l}\text { Amazônia } \\
\text { ocidental }\end{array}$ & Orinoco & Yanomami & $\begin{array}{l}\text { Contempo- } \\
\text { râneo }\end{array}$ \\
\hline $\begin{array}{l}\quad \text { Banco } \\
\text { xamânico em } \\
\text { formato de } \\
\text { pássaro }\end{array}$ & Brasil central & Xingu & Kamayura & $\begin{array}{l}\text { Contempo- } \\
\text { râneo }\end{array}$ \\
\hline $\begin{array}{l}\text { Tipoia, } \\
\text { carregador de } \\
\text { crianças }\end{array}$ & Brasil central & Xingú & Kayapó & $\begin{array}{l}\text { Contempo- } \\
\text { râneo }\end{array}$ \\
\hline Borduna & Brasil central & Xingú & Kayapó & $\begin{array}{l}\text { Contempo- } \\
\text { râneo }\end{array}$ \\
\hline $\begin{array}{l}\text { Arcos e } \\
\text { flechas }\end{array}$ & Brasil central & Xingú & Kamayura & $\begin{array}{l}\text { Contempo- } \\
\text { râneo }\end{array}$ \\
\hline Tipitì & $\begin{array}{l}\text { Amazônia } \\
\text { ocidental }\end{array}$ & Rio Vaupes & Tukano & $\begin{array}{l}\text { Contempo- } \\
\text { râneo }\end{array}$ \\
\hline $\begin{array}{l}\text { Aljava com } \\
\text { flechas }\end{array}$ & $\begin{array}{l}\text { Amazônia } \\
\text { ocidental }\end{array}$ & $\begin{array}{l}\text { Rio Negro / } \\
\text { Rio Vaupes }\end{array}$ & Macu (?) & $\begin{array}{l}\text { Contempo- } \\
\text { râneo }\end{array}$ \\
\hline $\begin{array}{l}\text { Ornamento } \\
\text { pectoral com } \\
\text { plumas }\end{array}$ & Amazônia & Pará & $\begin{array}{l}\text { Não identifi- } \\
\text { cado }\end{array}$ & $\begin{array}{l}\text { Contempo- } \\
\text { râneo }\end{array}$ \\
\hline
\end{tabular}


ANTHROPOLÓGICAS 30(2):63-90, 2019

\begin{tabular}{|c|c|c|c|c|}
\hline $\begin{array}{l}\text { Braceletes } \\
\text { rituais }\end{array}$ & $\begin{array}{l}\text { Brasil Cen- } \\
\text { tral }\end{array}$ & Mato Grosso & Iranche & $\begin{array}{l}\text { Contempo- } \\
\text { râneo }\end{array}$ \\
\hline $\begin{array}{l}\text { Ornamento } \\
\text { plumário. }\end{array}$ & Brasil central & Xingú & Kamayura & $\begin{array}{l}\text { Contempo- } \\
\text { râneo }\end{array}$ \\
\hline $\begin{array}{l}\text { Braceletes } \\
\text { rituais }\end{array}$ & Brasil central & Xingú & Kamayura & $\begin{array}{l}\text { Contempo- } \\
\text { râneo }\end{array}$ \\
\hline $\begin{array}{l}\text { Vestimenta } \\
\text { feminina em } \\
\text { fibras vegetais }\end{array}$ & Brasil central & Xingú & $\begin{array}{l}\text { Não identifi- } \\
\text { cado }\end{array}$ & $\begin{array}{l}\text { Contempo- } \\
\text { râneo }\end{array}$ \\
\hline $\begin{array}{l}\text { Tambor } \\
\text { xamânico }\end{array}$ & Brasil & Rio Mapuera & Wai-wai & $\begin{array}{l}\text { Contempo- } \\
\text { râneo }\end{array}$ \\
\hline $\begin{array}{l}\text { Cesto para } \\
\text { carregar }\end{array}$ & Brasil central & Xingú & Meinaco & $\begin{array}{l}\text { Contempo- } \\
\text { râneo }\end{array}$ \\
\hline Cesto urutu & $\begin{array}{l}\text { Amazônia } \\
\text { ocidental }\end{array}$ & Rio Vaupes & Tukano & $\begin{array}{l}\text { Contempo- } \\
\text { râneo }\end{array}$ \\
\hline Cesto warao & $\begin{array}{l}\text { Brasil Co- } \\
\text { lômbia }\end{array}$ & $\begin{array}{l}\text { Vale do Ori- } \\
\text { noco }\end{array}$ & Moriche & $\begin{array}{l}\text { Contempo- } \\
\text { râneo }\end{array}$ \\
\hline $\begin{array}{l}\text { Leque para } \\
\text { o fogo }\end{array}$ & $\begin{array}{l}\text { Amazônia } \\
\text { ocidental }\end{array}$ & Rio Vaupes & Tukano & $\begin{array}{l}\text { Contempo- } \\
\text { râneo }\end{array}$ \\
\hline $\begin{array}{l}\text { Capacete } \\
\text { plumário }\end{array}$ & Brasil central & Araguaia & Karajá & $\begin{array}{l}\text { Contempo- } \\
\text { râneo }\end{array}$ \\
\hline $\begin{array}{l}\text { Vestido } \\
\text { funerário }\end{array}$ & Brasil central & Xingú & Kayapó & $\begin{array}{l}\text { Contempo- } \\
\text { râneo }\end{array}$ \\
\hline Cesto warao & $\begin{array}{l}\text { Brasil Co- } \\
\text { lômbia }\end{array}$ & $\begin{array}{l}\text { Vale do Ori- } \\
\text { noco }\end{array}$ & Moriche & $\begin{array}{l}\text { Contempo- } \\
\text { râneo }\end{array}$ \\
\hline Cesto warao & $\begin{array}{l}\text { Brasil Co- } \\
\text { lômbia }\end{array}$ & $\begin{array}{l}\text { Vale do Ori- } \\
\text { noco }\end{array}$ & Moriche & $\begin{array}{l}\text { Contempo- } \\
\text { râneo }\end{array}$ \\
\hline $\begin{array}{l}\text { Aljava para } \\
\text { flechas de } \\
\text { zarabatana }\end{array}$ & $\begin{array}{l}\text { Amazônia } \\
\text { ocidental }\end{array}$ & Rio Negro & Macu (?) & $\begin{array}{l}\text { Contempo- } \\
\text { râneo }\end{array}$ \\
\hline $\begin{array}{l}\text { Vestido } \\
\text { funerário }\end{array}$ & Brasil central & Xingú & Kamayura & $\begin{array}{l}\text { Contempo- } \\
\text { râneo }\end{array}$ \\
\hline $\begin{array}{l}\text { Capacete } \\
\text { em plumas de } \\
\text { arara }\end{array}$ & $\begin{array}{l}\text { Brasil Orien- } \\
\text { tal }\end{array}$ & Maranhão & Guajajara & $\begin{array}{l}\text { Contempo- } \\
\text { râneo }\end{array}$ \\
\hline Tanga & Guiana & Guiana & Wai-Wai & $\begin{array}{l}\text { Contempo- } \\
\text { râneo }\end{array}$ \\
\hline $\begin{array}{l}\text { Artefato } \\
\text { para segurar } \\
\text { charuto }\end{array}$ & $\begin{array}{l}\text { Amazônia } \\
\text { ocidental }\end{array}$ & Rio Vaupes & Tukano & $\begin{array}{l}\text { Contempo- } \\
\text { râneo }\end{array}$ \\
\hline
\end{tabular}




\begin{tabular}{|c|c|c|c|c|}
\hline $\begin{array}{l}\text { Cesto } \\
\text { urutú. }\end{array}$ & $\begin{array}{l}\text { Amazônia } \\
\text { ocidental }\end{array}$ & Rio Negro & Tukano & $\begin{array}{l}\text { Contempo- } \\
\text { râneo }\end{array}$ \\
\hline $\begin{array}{l}\text { Capacete } \\
\text { plumário }\end{array}$ & Brasil central & Araguaia & Karajá & $\begin{array}{l}\text { Contempo- } \\
\text { râneo }\end{array}$ \\
\hline Boneca & Brasil central & Araguaia & Karajá & $\begin{array}{l}\text { Contempo- } \\
\text { râneo }\end{array}$ \\
\hline Boneca & Brasil central & Araguaia & Karajá & $\begin{array}{l}\text { Contempo- } \\
\text { râneo }\end{array}$ \\
\hline Boneca & Brasil central & Araguaia & Karajá & $\begin{array}{l}\text { Contempo- } \\
\text { râneo }\end{array}$ \\
\hline Boneca & Brasil central & Araguaia & Karajá & $\begin{array}{l}\text { Contempo- } \\
\text { râneo }\end{array}$ \\
\hline Cesto & $\begin{array}{l}\text { Não identifi- } \\
\text { cado }\end{array}$ & $\begin{array}{l}\text { Não identifi- } \\
\text { cado }\end{array}$ & $\begin{array}{l}\text { Não identifi- } \\
\text { cado }\end{array}$ & $\begin{array}{l}\text { Contempo- } \\
\text { râneo }\end{array}$ \\
\hline Cesto & $\begin{array}{l}\text { Não identifi- } \\
\text { cado }\end{array}$ & $\begin{array}{l}\text { Não identifi- } \\
\text { cado }\end{array}$ & $\begin{array}{l}\text { Não identifi- } \\
\text { cado }\end{array}$ & $\begin{array}{l}\text { Contempo- } \\
\text { râneo }\end{array}$ \\
\hline Flecha & $\begin{array}{l}\text { Não identifi- } \\
\text { cado }\end{array}$ & $\begin{array}{l}\text { Não identifi- } \\
\text { cado }\end{array}$ & $\begin{array}{l}\text { Não identifi- } \\
\text { cado }\end{array}$ & $\begin{array}{l}\text { Não identifi- } \\
\text { cado }\end{array}$ \\
\hline Flecha & $\begin{array}{l}\text { Não identifi- } \\
\text { cado }\end{array}$ & $\begin{array}{l}\text { Não identifi- } \\
\text { cado }\end{array}$ & $\begin{array}{l}\text { Não identifi- } \\
\text { cado }\end{array}$ & $\begin{array}{l}\text { Não identifi- } \\
\text { cado }\end{array}$ \\
\hline Decoração & Brasil central & $\begin{array}{l}\text { Não identifi- } \\
\text { cado }\end{array}$ & $\begin{array}{l}\text { Não identifi- } \\
\text { cado }\end{array}$ & $\begin{array}{l}\text { Não identifi- } \\
\text { cado }\end{array}$ \\
\hline Flecha & $\begin{array}{l}\text { Não identifi- } \\
\text { cado }\end{array}$ & $\begin{array}{l}\text { Não identifi- } \\
\text { cado }\end{array}$ & $\begin{array}{l}\text { Não identifi- } \\
\text { cado }\end{array}$ & $\begin{array}{l}\text { Contempo- } \\
\text { râneo }\end{array}$ \\
\hline $\begin{array}{c}\text { Banco } \\
\text { xamânico }\end{array}$ & Brasil & Rio Mapuera & Wai-wai & $\begin{array}{l}\text { Contempo- } \\
\text { râneo }\end{array}$ \\
\hline $\begin{array}{c}\text { Banco } \\
\text { xamânico }\end{array}$ & $\begin{array}{l}\text { Não identifi- } \\
\text { cado }\end{array}$ & $\begin{array}{l}\text { Não identifi- } \\
\text { cado }\end{array}$ & $\begin{array}{l}\text { Não identifi- } \\
\text { cado }\end{array}$ & $\begin{array}{l}\text { Contempo- } \\
\text { râneo }\end{array}$ \\
\hline Maracás & $\begin{array}{l}\text { Não identifi- } \\
\text { cado }\end{array}$ & $\begin{array}{l}\text { Não identifi- } \\
\text { cado }\end{array}$ & $\begin{array}{l}\text { Não identifi- } \\
\text { cado }\end{array}$ & $\begin{array}{l}\text { Não identifi- } \\
\text { cado }\end{array}$ \\
\hline Maracás & $\begin{array}{l}\text { Não identifi- } \\
\text { cado }\end{array}$ & $\begin{array}{l}\text { Não identifi- } \\
\text { cado }\end{array}$ & $\begin{array}{l}\text { Não identifi- } \\
\text { cado }\end{array}$ & $\begin{array}{l}\text { Não identifi- } \\
\text { cado }\end{array}$ \\
\hline Canastra & $\begin{array}{l}\text { Não identifi- } \\
\text { cado }\end{array}$ & $\begin{array}{l}\text { Não identifi- } \\
\text { cado }\end{array}$ & $\begin{array}{l}\text { Não identifi- } \\
\text { cado }\end{array}$ & $\begin{array}{l}\text { Contempo- } \\
\text { râneo }\end{array}$ \\
\hline Arco & $\begin{array}{l}\text { Brasil Cen- } \\
\text { tral }\end{array}$ & Rio Bakaja & $\begin{array}{l}\text { Meben- } \\
\text { gokré-Xikrin } \\
\text { (Kayapó) }\end{array}$ & $\begin{array}{l}\text { Contempo- } \\
\text { râneo }\end{array}$ \\
\hline Flecha & $\begin{array}{l}\text { Brasil Cen- } \\
\text { tral }\end{array}$ & Rio Bakaja & $\begin{array}{l}\text { Mebengokré } \\
\text {-Xikrin (Kaya- } \\
\text { po) }\end{array}$ & $\begin{array}{l}\text { Contempo- } \\
\text { râneo }\end{array}$ \\
\hline
\end{tabular}


ANTHROPOLÓGICAS 30(2):63-90, 2019

\begin{tabular}{|c|c|c|c|c|}
\hline Flecha & $\begin{array}{l}\text { Brasil Cen- } \\
\text { tral }\end{array}$ & Rio Bakaja & $\begin{array}{l}\text { Mebengokré } \\
\text {-Xikrin (Kaya- } \\
\text { po) }\end{array}$ & $\begin{array}{l}\text { Contempo- } \\
\text { râneo }\end{array}$ \\
\hline Flecha & $\begin{array}{l}\text { Brasil Cen- } \\
\text { tral }\end{array}$ & Rio Bakaja & $\begin{array}{l}\text { Mebengokré } \\
\text {-Xikrin (Kaya- } \\
\text { po) }\end{array}$ & $\begin{array}{l}\text { Contempo- } \\
\text { râneo }\end{array}$ \\
\hline Borduna & $\begin{array}{l}\text { Brasil Cen- } \\
\text { tral }\end{array}$ & Rio Bakaja & $\begin{array}{l}\text { Mebengokré } \\
\text {-Xikrin (Kaya- } \\
\text { po) }\end{array}$ & $\begin{array}{l}\text { Contempo- } \\
\text { râneo }\end{array}$ \\
\hline Colar & $\begin{array}{l}\text { Brasil Cen- } \\
\text { tral }\end{array}$ & Rio Bakaja & $\begin{array}{l}\text { Mebengokré } \\
\text {-Xikrin (Kaya- } \\
\text { po) }\end{array}$ & $\begin{array}{l}\text { Contempo- } \\
\text { râneo }\end{array}$ \\
\hline $\begin{array}{l}\text { Vestido } \\
\text { ritual da } \\
\text { menarca }\end{array}$ & $\begin{array}{l}\text { Amazônia } \\
\text { ocidental }\end{array}$ & Rio Negro & Tukano & $\begin{array}{l}\text { Contempo- } \\
\text { râneo }\end{array}$ \\
\hline $\begin{array}{l}\quad \text { Estaátua } \\
\text { representando } \\
\text { uma figura } \\
\text { animal }\end{array}$ & $\begin{array}{l}\text { Brasil Cen- } \\
\text { tral }\end{array}$ & Araguaia & Karajá & $\begin{array}{l}\text { Contempo- } \\
\text { râneo }\end{array}$ \\
\hline $\begin{array}{l}\text { Capacete } \\
\text { plumario }\end{array}$ & Brasil central & $\begin{array}{l}\text { Não identifi- } \\
\text { cado }\end{array}$ & $\begin{array}{l}\text { Não identifi- } \\
\text { cado }\end{array}$ & $\begin{array}{l}\text { Contempo- } \\
\text { râneo }\end{array}$ \\
\hline Braceletes & Brasil central & $\begin{array}{l}\text { Não identifi- } \\
\text { cado }\end{array}$ & $\begin{array}{l}\text { Não identifi- } \\
\text { cado }\end{array}$ & $\begin{array}{l}\text { Contempo- } \\
\text { râneo }\end{array}$ \\
\hline Zarabatana & $\begin{array}{l}\text { Amazônia } \\
\text { ocidental }\end{array}$ & Rio Negro & Macu (?) & $\begin{array}{l}\text { Contempo- } \\
\text { râneo }\end{array}$ \\
\hline $\begin{array}{l}\text { Aljava para } \\
\text { flechas de } \\
\text { zarabatana }\end{array}$ & $\begin{array}{l}\text { Amazônia } \\
\text { ocidental }\end{array}$ & Rio Negro & Macu (?) & $\begin{array}{l}\text { Contempo- } \\
\text { râneo }\end{array}$ \\
\hline Zarabatana & $\begin{array}{l}\text { Amazônia } \\
\text { Ocidental }\end{array}$ & Rio Negro & Macu (?) & $\begin{array}{l}\text { Contempo- } \\
\text { râneo }\end{array}$ \\
\hline $\begin{array}{l}\text { Capacete } \\
\text { plumário }\end{array}$ & Brasil central & $\begin{array}{l}\text { Não identifi- } \\
\text { cado }\end{array}$ & $\begin{array}{l}\text { Não identifi- } \\
\text { cado }\end{array}$ & $\begin{array}{l}\text { Contempo- } \\
\text { râneo }\end{array}$ \\
\hline Braceletes & Brasil central & $\begin{array}{l}\text { Não identifi- } \\
\text { cado }\end{array}$ & $\begin{array}{l}\text { Não identifi- } \\
\text { cado }\end{array}$ & $\begin{array}{l}\text { Contempo- } \\
\text { râneo }\end{array}$ \\
\hline Braceletes & Brasil central & $\begin{array}{l}\text { Não identifi- } \\
\text { cado }\end{array}$ & $\begin{array}{l}\text { Não identifi- } \\
\text { cado }\end{array}$ & $\begin{array}{l}\text { Contempo- } \\
\text { râneo }\end{array}$ \\
\hline $\begin{array}{l}\text { Capacete } \\
\text { plumário }\end{array}$ & Brasil central & $\begin{array}{l}\text { Não identifi- } \\
\text { cado }\end{array}$ & $\begin{array}{l}\text { Não identifi- } \\
\text { cado }\end{array}$ & $\begin{array}{l}\text { Contempo- } \\
\text { râneo }\end{array}$ \\
\hline Peneira & $\begin{array}{l}\text { Não identifi- } \\
\text { cado }\end{array}$ & $\begin{array}{l}\text { Não identifi- } \\
\text { cado }\end{array}$ & Tupi-Guarani & $\begin{array}{l}\text { Contempo- } \\
\text { râneo }\end{array}$ \\
\hline Arco & Brasil & $\begin{array}{l}\text { Não identifi- } \\
\text { cado }\end{array}$ & $\begin{array}{l}\text { Não identifi- } \\
\text { cado }\end{array}$ & $\begin{array}{l}\text { Contempo- } \\
\text { râneo }\end{array}$ \\
\hline
\end{tabular}




\begin{tabular}{|c|c|c|c|c|}
\hline $\begin{array}{l}\text { Capacete } \\
\text { plumário }\end{array}$ & Brasil & $\begin{array}{l}\text { Não identifi- } \\
\text { cado }\end{array}$ & $\begin{array}{l}\text { Não identifi- } \\
\text { cado }\end{array}$ & $\begin{array}{l}\text { Contempo- } \\
\text { râneo }\end{array}$ \\
\hline Borduna & Brasil central & Araguaia & Karajá & $\begin{array}{l}\text { Contempo- } \\
\text { râneo }\end{array}$ \\
\hline Peneira & $\begin{array}{l}\text { Não identifi- } \\
\text { cado }\end{array}$ & $\begin{array}{l}\text { Não identifi- } \\
\text { cado }\end{array}$ & Tupi-Guarani & $\begin{array}{l}\text { Contempo- } \\
\text { râneo }\end{array}$ \\
\hline Peneira & $\begin{array}{l}\text { Não identifi- } \\
\text { cado }\end{array}$ & $\begin{array}{l}\text { Não identifi- } \\
\text { cado }\end{array}$ & Tupi-Guarani & $\begin{array}{l}\text { Contempo- } \\
\text { râneo }\end{array}$ \\
\hline $\begin{array}{c}\text { Tanga } \\
\text { feminina }\end{array}$ & Roraima & Abonari & $\begin{array}{l}\text { Waimiri-A- } \\
\text { troari }\end{array}$ & $\begin{array}{l}\text { Contempo- } \\
\text { râneo }\end{array}$ \\
\hline Cesta & $\begin{array}{l}\text { Brasil Cen- } \\
\text { tral }\end{array}$ & Rio Tocantins & Xerente & $\begin{array}{l}\text { Contempo- } \\
\text { râneo }\end{array}$ \\
\hline $\begin{array}{l}\text { Capacete } \\
\text { plumário }\end{array}$ & $\begin{array}{l}\text { Não identifi- } \\
\text { cado }\end{array}$ & $\begin{array}{l}\text { Não identifi- } \\
\text { cado }\end{array}$ & $\begin{array}{l}\text { Não identifi- } \\
\text { cado }\end{array}$ & $\begin{array}{l}\text { Contempo- } \\
\text { râneo }\end{array}$ \\
\hline Flecha & $\begin{array}{l}\text { Não identifi- } \\
\text { cado }\end{array}$ & $\begin{array}{l}\text { Não identifi- } \\
\text { cado }\end{array}$ & $\begin{array}{l}\text { Não identifi- } \\
\text { cado }\end{array}$ & $\begin{array}{l}\text { Contempo- } \\
\text { râneo }\end{array}$ \\
\hline Flecha & $\begin{array}{l}\text { Não identifi- } \\
\text { cado }\end{array}$ & $\begin{array}{l}\text { Não identifi- } \\
\text { cado }\end{array}$ & $\begin{array}{l}\text { Não identifi- } \\
\text { cado }\end{array}$ & $\begin{array}{l}\text { Contempo- } \\
\text { râneo }\end{array}$ \\
\hline Flecha & $\begin{array}{l}\text { Não identifi- } \\
\text { cado }\end{array}$ & $\begin{array}{l}\text { Não identifi- } \\
\text { cado }\end{array}$ & $\begin{array}{l}\text { Não identifi- } \\
\text { cado }\end{array}$ & $\begin{array}{l}\text { Contempo- } \\
\text { râneo }\end{array}$ \\
\hline Flecha & $\begin{array}{l}\text { Não identifi- } \\
\text { cado }\end{array}$ & $\begin{array}{l}\text { Não identifi- } \\
\text { cado }\end{array}$ & $\begin{array}{l}\text { Não identifi- } \\
\text { cado }\end{array}$ & $\begin{array}{l}\text { Contempo- } \\
\text { râneo }\end{array}$ \\
\hline Flecha & $\begin{array}{l}\text { Não identifi- } \\
\text { cado }\end{array}$ & $\begin{array}{l}\text { Não identifi- } \\
\text { cado }\end{array}$ & $\begin{array}{l}\text { Não identifi- } \\
\text { cado }\end{array}$ & $\begin{array}{l}\text { Contempo- } \\
\text { râneo }\end{array}$ \\
\hline $\begin{array}{l}\text { Ralador de } \\
\text { mandioca }\end{array}$ & $\begin{array}{l}\text { Amazônia } \\
\text { ocidental }\end{array}$ & Rio Vaupes & Tukano & $\begin{array}{l}\text { Contempo- } \\
\text { râneo }\end{array}$ \\
\hline $\begin{array}{l}\text { Ralador de } \\
\text { mandioca }\end{array}$ & Brasil & Guiana & Wai-Wai & $\begin{array}{l}\text { Contempo- } \\
\text { râneo }\end{array}$ \\
\hline Maloca & $\begin{array}{l}\text { Amazônia } \\
\text { ocidental }\end{array}$ & Orinoco & Yanomami & $\begin{array}{l}\text { Contempo- } \\
\text { râneo }\end{array}$ \\
\hline Capacete & Brasil central & Xingu & Txucarramaes & $\begin{array}{l}\text { Contempo- } \\
\text { râneo }\end{array}$ \\
\hline Vasilha & Brasil central & Xingu & Assurini & $\begin{array}{l}\text { Contempo- } \\
\text { râneo }\end{array}$ \\
\hline Vasilha & Brasil central & Xingu & Assurini & $\begin{array}{l}\text { Contempo- } \\
\text { râneo }\end{array}$ \\
\hline Vasilha & Brasil central & Xingu & Assurini & $\begin{array}{l}\text { Contempo- } \\
\text { râneo }\end{array}$ \\
\hline $\begin{array}{l}\text { Estatueta } \\
\text { zoomorfa }\end{array}$ & $\begin{array}{l}\text { Amazônia } \\
\text { ocidental }\end{array}$ & Rio Solimões & Tikuna & $\begin{array}{l}\text { Contempo- } \\
\text { râneo }\end{array}$ \\
\hline
\end{tabular}


ANTHROPOLÓGICAS 30(2):63-90, 2019

\begin{tabular}{|c|c|c|c|c|}
\hline Cesta & $\begin{array}{l}\text { Amazônia } \\
\text { ocidental }\end{array}$ & Rio Solimões & Tukano & $\begin{array}{l}\text { Contempo- } \\
\text { râneo }\end{array}$ \\
\hline Cesta & $\begin{array}{l}\text { Amazônia } \\
\text { ocidental }\end{array}$ & Rio Solimões & Yanomami & $\begin{array}{l}\text { Contempo- } \\
\text { râneo }\end{array}$ \\
\hline Ralador & $\begin{array}{l}\text { Amazônia } \\
\text { ocidental }\end{array}$ & Rio Solimões & $\begin{array}{l}\text { Não identifi- } \\
\text { cado }\end{array}$ & $\begin{array}{l}\text { Contempo- } \\
\text { râneo }\end{array}$ \\
\hline $\begin{array}{l}\text { Ralador } \\
\text { pequeno }\end{array}$ & $\begin{array}{l}\text { Amazônia } \\
\text { Ocidental }\end{array}$ & Rio Solimões & $\begin{array}{l}\text { Não identifi- } \\
\text { cado }\end{array}$ & $\begin{array}{l}\text { Contempo- } \\
\text { râneo }\end{array}$ \\
\hline $\begin{array}{l}\text { Estatueta } \\
\text { zoomorfa }\end{array}$ & $\begin{array}{l}\text { Amazônia } \\
\text { ocidental }\end{array}$ & Rio Solimões & Tikuna & $\begin{array}{l}\text { Contempo- } \\
\text { râneo }\end{array}$ \\
\hline Braceletes & Brasil & Rio Itui & Matis & $\begin{array}{l}\text { Contempo- } \\
\text { râneo }\end{array}$ \\
\hline Arco & Perú & $\begin{array}{l}\text { Rio Madre de } \\
\text { Dios }\end{array}$ & Ese Ejja & $\begin{array}{l}\text { Contempo- } \\
\text { râneo }\end{array}$ \\
\hline Flecha & Perú & $\begin{array}{l}\text { Rio Madre de } \\
\text { Dios }\end{array}$ & Ese Ejja & $\begin{array}{l}\text { Contempo- } \\
\text { râneo }\end{array}$ \\
\hline Flecha & Perú & $\begin{array}{l}\text { Rio Madre de } \\
\text { Dios }\end{array}$ & Ese Ejja & $\begin{array}{l}\text { Contempo- } \\
\text { râneo }\end{array}$ \\
\hline Arco & Perú & $\begin{array}{l}\text { Rio Madre de } \\
\text { Dios }\end{array}$ & Ese Ejja & $\begin{array}{l}\text { Contempo- } \\
\text { râneo }\end{array}$ \\
\hline Flecha & Perú & $\begin{array}{l}\text { Rio Madre de } \\
\text { Dios }\end{array}$ & Ese Ejja & $\begin{array}{l}\text { Contempo- } \\
\text { râneo }\end{array}$ \\
\hline Flecha & Perú & $\begin{array}{l}\text { Rio Madre de } \\
\text { Dios }\end{array}$ & Ese Ejja & $\begin{array}{l}\text { Contempo- } \\
\text { râneo }\end{array}$ \\
\hline Arco & Perú & $\begin{array}{l}\text { Rio Madre de } \\
\text { Dios }\end{array}$ & Ese Ejja & $\begin{array}{l}\text { Contempo- } \\
\text { râneo }\end{array}$ \\
\hline Banco ritual & $\begin{array}{l}\text { Amazônia } \\
\text { ocidental }\end{array}$ & Rio Solimoẽs & Tikuna & $\begin{array}{l}\text { Contempo- } \\
\text { râneo }\end{array}$ \\
\hline Flecha & Perú & $\begin{array}{l}\text { Rio Madre de } \\
\text { Dios }\end{array}$ & Ese Ejja & $\begin{array}{l}\text { Contempo- } \\
\text { râneo }\end{array}$ \\
\hline Flecha & Perú & $\begin{array}{l}\text { Rio Madre de } \\
\text { Dios }\end{array}$ & Ese Ejja & $\begin{array}{l}\text { Contempo- } \\
\text { râneo }\end{array}$ \\
\hline Estandarte & $\begin{array}{l}\text { Não identifi- } \\
\text { cado }\end{array}$ & $\begin{array}{l}\text { Não identifi- } \\
\text { cado }\end{array}$ & $\begin{array}{l}\text { Não identifi- } \\
\text { cado }\end{array}$ & $\begin{array}{l}\text { Contempo- } \\
\text { râneo }\end{array}$ \\
\hline Vasilha & $\begin{array}{l}\text { Não identifi- } \\
\text { cado }\end{array}$ & $\begin{array}{l}\text { Não identifi- } \\
\text { cado }\end{array}$ & Kechua & $\begin{array}{l}\text { Contempo- } \\
\text { râneo }\end{array}$ \\
\hline $\begin{array}{r}\text { Rombo } \\
\text { (Nafukua) }\end{array}$ & Brasil central & Xingú & & $\begin{array}{l}\text { Contempo- } \\
\text { râneo }\end{array}$ \\
\hline $\begin{array}{l}\text { Tiara plu- } \\
\text { mada }\end{array}$ & $\begin{array}{l}\text { Amazônia } \\
\text { ocidental }\end{array}$ & Rio Solimões & Tikuna & $\begin{array}{l}\text { Contempo- } \\
\text { râneo }\end{array}$ \\
\hline
\end{tabular}


Bollettin: As Vidas dos Artefatos

\begin{tabular}{|c|c|c|c|c|}
\hline Luva ritual & Brasil & Guiana & Sateré-Mawé & $\begin{array}{l}\text { Contempo- } \\
\text { râneo }\end{array}$ \\
\hline Cesta & Brasil & Guiana & Sateré-Mawé & $\begin{array}{l}\text { Contempo- } \\
\text { râneo }\end{array}$ \\
\hline Cesta & $\begin{array}{l}\text { Amazônia } \\
\text { ocidental }\end{array}$ & Rio Solimões & Tukano & $\begin{array}{l}\text { Contempo- } \\
\text { râneo }\end{array}$ \\
\hline Cesta & $\begin{array}{l}\text { Amazônia } \\
\text { ocidental }\end{array}$ & Rio Solimões & Tukano & $\begin{array}{l}\text { Contempo- } \\
\text { râneo }\end{array}$ \\
\hline Cesta & $\begin{array}{l}\text { Amazônia } \\
\text { ocidental }\end{array}$ & Rio Solimões & Tukano & $\begin{array}{l}\text { Contempo- } \\
\text { râneo }\end{array}$ \\
\hline $\begin{array}{l}\text { Brincos de } \\
\text { plumas }\end{array}$ & $\begin{array}{l}\text { Não identifi- } \\
\text { cado }\end{array}$ & $\begin{array}{l}\text { Não identifi- } \\
\text { cado }\end{array}$ & $\begin{array}{l}\text { Não identifi- } \\
\text { cado }\end{array}$ & $\begin{array}{l}\text { Não identifi- } \\
\text { cado }\end{array}$ \\
\hline $\begin{array}{l}\text { Brincos de } \\
\text { plumas }\end{array}$ & $\begin{array}{l}\text { Não identifi- } \\
\text { cado }\end{array}$ & $\begin{array}{l}\text { Não identifi- } \\
\text { cado }\end{array}$ & $\begin{array}{l}\text { Não identifi- } \\
\text { cado }\end{array}$ & $\begin{array}{l}\text { Não identifi- } \\
\text { cado }\end{array}$ \\
\hline $\begin{array}{l}\text { Brincos de } \\
\text { plumas }\end{array}$ & $\begin{array}{l}\text { Não identifi- } \\
\text { cado }\end{array}$ & $\begin{array}{l}\text { Não identifi- } \\
\text { cado }\end{array}$ & $\begin{array}{l}\text { Não identifi- } \\
\text { cado }\end{array}$ & $\begin{array}{l}\text { Não identifi- } \\
\text { cado }\end{array}$ \\
\hline $\begin{array}{l}\text { Brincos de } \\
\text { plumas }\end{array}$ & $\begin{array}{l}\text { Não identifi- } \\
\text { cado }\end{array}$ & $\begin{array}{l}\text { Não identifi- } \\
\text { cado }\end{array}$ & $\begin{array}{l}\text { Não identifi- } \\
\text { cado }\end{array}$ & $\begin{array}{l}\text { Não identifi- } \\
\text { cado }\end{array}$ \\
\hline $\begin{array}{l}\text { Brincos de } \\
\text { plumas }\end{array}$ & $\begin{array}{l}\text { Não identifi- } \\
\text { cado }\end{array}$ & $\begin{array}{l}\text { Não identifi- } \\
\text { cado }\end{array}$ & $\begin{array}{l}\text { Não identifi- } \\
\text { cado }\end{array}$ & $\begin{array}{l}\text { Não identifi- } \\
\text { cado }\end{array}$ \\
\hline Braceletes & $\begin{array}{l}\text { Não identifi- } \\
\text { cado }\end{array}$ & $\begin{array}{l}\text { Não identifi- } \\
\text { cado }\end{array}$ & $\begin{array}{l}\text { Não identifi- } \\
\text { cado }\end{array}$ & $\begin{array}{l}\text { Não identifi- } \\
\text { cado }\end{array}$ \\
\hline $\begin{array}{l}\text { Pente para } \\
\text { cabelos }\end{array}$ & $\begin{array}{l}\text { Não identifi- } \\
\text { cado }\end{array}$ & $\begin{array}{l}\text { Não identifi- } \\
\text { cado }\end{array}$ & $\begin{array}{l}\text { Não identifi- } \\
\text { cado }\end{array}$ & $\begin{array}{l}\text { Não identifi- } \\
\text { cado }\end{array}$ \\
\hline $\begin{array}{l}\text { Pente para } \\
\text { cabelos }\end{array}$ & $\begin{array}{l}\text { Não identifi- } \\
\text { cado }\end{array}$ & $\begin{array}{l}\text { Não identifi- } \\
\text { cado }\end{array}$ & $\begin{array}{l}\text { Não identifi- } \\
\text { cado }\end{array}$ & $\begin{array}{l}\text { Não identifi- } \\
\text { cado }\end{array}$ \\
\hline Bolsa & $\begin{array}{l}\text { Não identifi- } \\
\text { cado }\end{array}$ & $\begin{array}{l}\text { Não identifi- } \\
\text { cado }\end{array}$ & $\begin{array}{l}\text { Não identifi- } \\
\text { cado }\end{array}$ & $\begin{array}{l}\text { Não identifi- } \\
\text { cado }\end{array}$ \\
\hline Arco & $\begin{array}{l}\text { Não identifi- } \\
\text { cado }\end{array}$ & $\begin{array}{l}\text { Não identifi- } \\
\text { cado }\end{array}$ & $\begin{array}{l}\text { Não identifi- } \\
\text { cado }\end{array}$ & $\begin{array}{l}\text { Não identifi- } \\
\text { cado }\end{array}$ \\
\hline Arco & $\begin{array}{l}\text { Não identifi- } \\
\text { cado }\end{array}$ & $\begin{array}{l}\text { Não identifi- } \\
\text { cado }\end{array}$ & $\begin{array}{l}\text { Não identifi- } \\
\text { cado }\end{array}$ & $\begin{array}{l}\text { Não identifi- } \\
\text { cado }\end{array}$ \\
\hline Arco & $\begin{array}{l}\text { Não identifi- } \\
\text { cado }\end{array}$ & $\begin{array}{l}\text { Não identifi- } \\
\text { cado }\end{array}$ & $\begin{array}{l}\text { Não identifi- } \\
\text { cado }\end{array}$ & $\begin{array}{l}\text { Não identifi- } \\
\text { cado }\end{array}$ \\
\hline Flecha & $\begin{array}{l}\text { Não identifi- } \\
\text { cado }\end{array}$ & $\begin{array}{l}\text { Não identifi- } \\
\text { cado }\end{array}$ & $\begin{array}{l}\text { Não identifi- } \\
\text { cado }\end{array}$ & $\begin{array}{l}\text { Não identifi- } \\
\text { cado }\end{array}$ \\
\hline $\begin{array}{l}\text { Mascara de } \\
\text { fibras vegetais }\end{array}$ & Perú & Iquitos & $\begin{array}{l}\text { Não identifi- } \\
\text { cado }\end{array}$ & $\begin{array}{l}\text { Contempo- } \\
\text { râneo }\end{array}$ \\
\hline
\end{tabular}


ANTHROPOLÓGICAS 30(2):63-90, 2019

\begin{tabular}{|c|l|l|l|l|}
\hline Flecha & $\begin{array}{l}\text { Não identifi- } \\
\text { cado }\end{array}$ & $\begin{array}{l}\text { Não identifi- } \\
\text { cado }\end{array}$ & $\begin{array}{l}\text { Não identifi- } \\
\text { cado }\end{array}$ & $\begin{array}{l}\text { Não identifi- } \\
\text { cado }\end{array}$ \\
\hline $\begin{array}{c}\text { Colar de } \\
\text { fragmentos de } \\
\text { casca de coco. }\end{array}$ & Xingu & $\begin{array}{l}\text { Não identifi- } \\
\text { cado }\end{array}$ & Kenzabi & $\begin{array}{l}\text { Contempo- } \\
\text { râneo }\end{array}$ \\
\hline Bonecas & Brasil central & Araguaia & Karajá & $\begin{array}{l}\text { Contempo- } \\
\text { râneo }\end{array}$ \\
\hline Cerâmicas & Brasil & Para & $\begin{array}{l}\text { Ilha de Ma- } \\
\text { rajó }\end{array}$ & $\begin{array}{l}\text { Contempo- } \\
\text { râneo }\end{array}$ \\
\hline Setaccio & $\begin{array}{l}\text { Não identifi- } \\
\text { cado }\end{array}$ & $\begin{array}{l}\text { Não identifi- } \\
\text { cado }\end{array}$ & Tupi-Guarani & $\begin{array}{l}\text { Contempo- } \\
\text { râneo }\end{array}$ \\
\hline
\end{tabular}

Os artefatos listados não são todos expostos na sala dedicada. Isso se deve a várias razões, principalmente a falta de espaços adequados para que todos eles possam ser adequadamente valorizados e apreciados pelo publico. Todavia, conforme mencionado acima, a Prefeitura da cidade de Perugia disponibilizou um novo espaço expositivo, onde será criada uma nova instalação que possivelmente possa permitir de tornar todos estes artefatos disponíveis ao publico. Com esse fim a equipe do Centro Studi Americanistici está realizando um intenso trabalho de identificação dos artefatos atualmente não completamente identificados. Ademais, novos artefatos são candidatos a entrar no acervo da coleção. O Centro Studi Americanistici está em fase de aquisição da coleção privada do etnólogo Gerardo Bamonte, composta por cerca de 600 artefatos, o que vai tornar numericamente a Coleção Etnográfica um dos principais acervos italiano sobre os povos amazônicos.

Cabe agora, depois de ter descrito o Centro de Documentação Audiovisual, a Coleção Etnográfica e seus membros, refletir sobre o efeito que estes artefatos têm na produção de encontros no contexto expositivo. Não se trata, nesse caso, de um 'museu indígena', como pode ser o celebre Museu Magüta (Oliveira 2012), ou de não ter uma efetiva e direta participação dos povos produtores dos artefatos na elaboração do percurso expositivo a exemplo do que acontece em vários casos brasileiros (Athias 2016; Velthem, Kukawa \& Joanny 2017; 
Russi 2019). Todavia, a tese é de que possa ser possível identificar uma efetiva agencia desses artefatos em uma dupla direção: enquanto mediadores entre os produtores e os frutidores e enquanto agentes dotados de vidas especificas próprias.

\section{A agentividade dos artefatos ameríndios}

Em uma coletânea já clássica, Fernando Santos-Granero (2009) introduz a experiência da vida subjetiva dos 'objetos materiais' entre os povos Ameríndios, que os produzem, os possuem, os circulam e os experienciam. Os textos dessa coletânea discutem como estes artefatos iluminam a diferença entre objetos (matéria inerte) e sujeitos (entidades dotadas de intencionalidade e agencia), sendo que se trataria de uma relacionalidade 'construtiva' na qual os corpos de humanos e artefatos são reciprocamente criados através de processos de 'fabricação'. No exemplo acima mencionado da borduna Mebengokré, fica evidente como o artefato é numa direção o 'fabricado' por Tedjore, mas ao mesmo tempo 'fabrica' o etnólogo inserindo-o num processo relacional, assim como os bordunas - enquanto categoria de artefatos/sujeitos produzem o guerreiro, o caçador, o orador, etc. Trata-se portanto de um processo relacional no qual os artefatos não podem ser reduzidos a uma materialidade inerte e passiva, mas sim devem ser observados em sua própria capacidade de acionar movimentos e encontros de sujeitos.

Essa direção de um reconhecimento dos artefatos, enquanto produtores de uma realidade relacional, já tinha sido apontada por Simondon (1989). Discutindo o tema, o filosofo francês aponta como os objetos técnicos, mas podemos aqui pensar também nos outros objetos da experiência cotidiana (Heidegger 1989), entram na nossa descrição dessa ultima através da dicotomia entre logos e tekhnè. A consequência, sempre de acordo com Simondon é a ausência da realidade própria do objeto, sendo este confiado à experiência que o humano tem dele. Reconhecer sua realidade própria significa inclui-lo na nossa descrição da experiência, não enquanto extensão, vicário ou residual, mas como dotado de um seu modo de existência. Nessa perspectiva, o 
objeto deve ser um motor de diferenciação e constituição do humano, pois ele não seria somente um instrumento do humano, mas sim um específico modo de existência que ordena o mundo.

Simondon nos sugere aqui uma inversão importante: ao invés de observar o objeto a partir do humano, deveríamos observar o humano a partir do objeto. Isso estaria ligado à ideia de que o objeto, o mundo do material, seria um dos caminhos através dos quais o humano emerge em sua existência. A proposta de Simondon aproxima o objeto do mundo material Ameríndio de forma evidente. Aqui, os sujeitos/objetos são concomitantemente resultado e produto de uma relação constitutiva entre os humanos e os artefatos. A borduna, como vimos, produz uma atualização da potencialidade caçadora ou guerreira ou política do Mebengokré. Ela constitui o agente da emergência dessa qualidade do humano.

Reconhecendo assim que o artefato não é um objeto inerte e passivo, mas sim algo que produz diferenças nos seus múltiplos movimentos. Como aponta Domínguez-Rubio ao discutir o trabalho de Simondon: "O objetivo, portanto, não é de estender a noção estrita de agencia humana a outras entidades, mas sim de estender a própria definição de agencia para incorporar agentividades distintas daquela humana" (Domínguez-Rubio 2008:96). Torna-se necessária, portanto uma separação analítica da noção de agencia da de agente. Numa proposta ampla de definição, a primeira poderia assim ser definida enquanto 'o poder de fazer algo'; o agente, por sua vez, seria "qualquer entidade que, em um ponto espaciotemporal especifico, possui a faculdade de introduzir uma diferença em um estado de coisas" (Domínguez-Rubio 2008:97). O que o agente faz, enfim, seria exatamente a diferença que introduz num estado anterior.

A mesma proposta de uma definição de agencia enquanto capacidade de produzir uma diferença num determinado estado de coisas já tinha sido sinalada também por outros autores tão diferentes como Bateson (1979), Giddens (1984), Gell (1998) e Latour (2005). Apesar das diferenças, as vezes radicais, entre esses autores, emerge um elemento comum que nos interessa na discussão que estamos levando 
a cabo aqui. Ademais, pensar os artefatos enquanto agentes leva a reconhecer que eles são 'vivos'. Uma vida que assume a forma de uma carreira social, uma biografia cultural e o poder de produzir encontros (Kopytoff 1986). Esses encontros, acionados na produção continua de diferenças envolvem reciprocamente os sujeitos sociais em recíprocas influencias (Tilley 2006). Assumindo que algo que produz uma diferença na situação inicial seja considerado agente, e que os encontros sejam os momentos nos quais tais diferenças são tornadas efetivas, então os artefatos presentes na Coleção Etnográfica do Centro Studi Americanistici são incluídos nessa categoria.

A borduna da qual descrevi a trajetória pode ser observada nesse prisma. Ela produz diferenças em toda sua trajetória biográfica: ela define Tedjore que a confecciona, o etnólogo que a recebe e a transporta até a Coleção Etnográfica, a própria exposição e enfim o visitante que com ela interage. Tedjore é reconhecido entre os Mebengokré como um dos anciões mais sábios do kukradjá, termo polissêmico que os Mebengokré glosam como 'cultura' e que se compõe de elementos materiais e imateriais (Bollettin 2019). Ao fazer a borduna para o kuben, o 'branco', ele assume a função de mediador entre sujeitos diferentes, entre os Mebengokré e o etnólogo que os visitou. Este, por sua vez, ao receber o presente, é transformado por este em um portador, mesmo que parcial do kukradjá, vindo a tornar-se outro do que era anteriormente. Ele é assim 'diferenciado', tornado 'diferente'. Isso é mais evidente no momento no qual a borduna chega à Coleção: o etnólogo deve ser uma 'ponte', um 'elo' entre os dois momentos da vida da borduna, a aldeia e a Coleção. Aqui a borduna expressa e atualiza mais do seu potencial agentivo. Ela redefine o espaço expositivo, colocada lado a lado com outros artefatos Mebengokré e de outros povos Ameríndios, ela aporta algo de novo, acrescenta uma nova possibilidade cognitiva à Coleção. Ademais, quando interage com os visitantes, ela permite a estes de mover-se na direção da produção de subjetividades Mebengokré, das lutas políticas desse povo, de suas atividades cotidianas. Os visitantes abandonam visões enraizadas e estereotipadas dos povos Ameríndios e 
a borduna revela a eles a contemporaneidade destes, suas dinamicidades e poliedricidades. Uma diferença, produzida num pedaço de madeira pelas mãos abeis de Tedjore, atua no outro lado do Atlântico.

No espaço da Coleção Etnográfica do Centro Studi Americanistici, portanto, podemos encontrar múltiplos encontros que os artefatos traçam ao longo de suas biografias. Não mais objetos inertes e passivos manuseado por sujeitos ativos, eles são agora agentes produtores de diferenças em seus encontros com outros atores. Mapeamos algumas dessas diferenças produzidas pela borduna Mebengokré, mas o mesmo poderia ser descrito pelos bancos xamânico do Rio Negro, pelos capacetes plumários do Rio Xingu e pelos outros componentes desse coletivo. Essa agencia permite encontros de outra forma mais improváveis. Os Mebengokré, os Tukano, os Maku, os Kamayurá e os outros povos Ameríndios cujos artefatos são incluídos na Coleção Etnográfica podem assim tornar-se participes de novos encontros. Eles podem assumir um papel ativo na sua própria auto-representação mesmo sem estar fisicamente presentes, pois quem define a emergência das diferentes subjetividades são os próprios artefatos, não simplesmente tradutores, mas produtores desses encontros e agentes das diferenças que afetam quem destes participa.

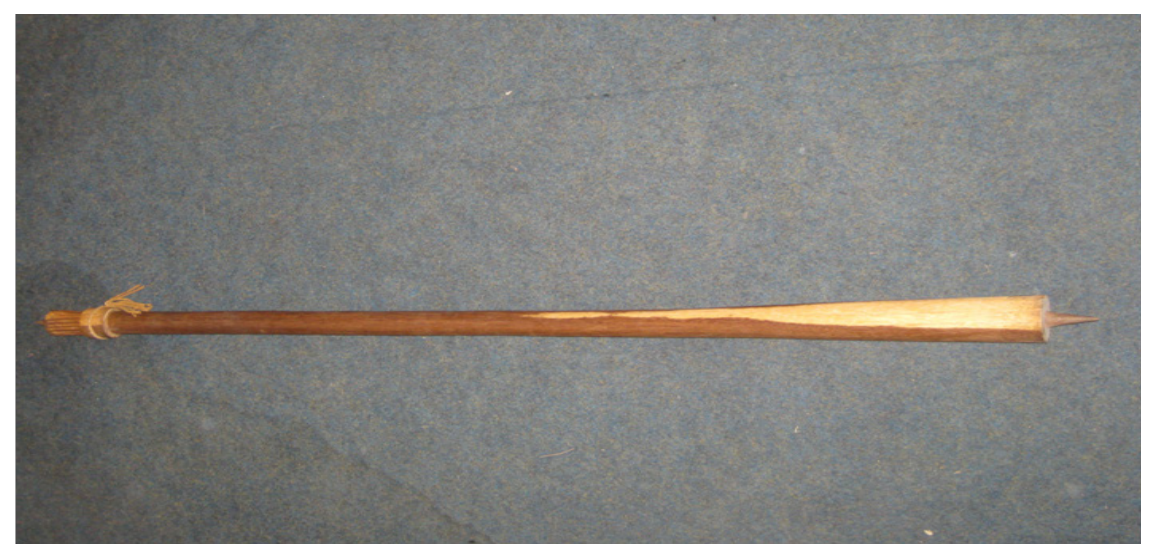

Imagem - Borduna Mebengokré. Foto de autoria de Bollettin Paride. 


\section{Referências:}

ATHIAS, Renato. 2016. "Objetos indígenas vivos em museus: temas e problemas sobre a patrimonialização". In: LIMA FILHO, M. F., ABREU, R. \& ATHIAS, R. (eds.): Museus e Atores Sociais: perspectivas antropológicas, pp. 189. 211. Recife: Editora da Universidade Federal do Pernambuco.

BATESON, Gregory. 1979. Mind and Nature: A Necessary Unit. New York: Dutton.

BOLLETTIN, Paride. 2019. Identità e Trasformazione: Processi del divenire in una comunità amazzonica. Padova: Cooperativa Libraria Università di Padova.

COHN, Clarice. 2005. Relações de diferença no Brasil Central. Tese de Doutorado. São Paulo: Universidade de São Paulo.

DOMÍNGUEZ-RUBIO, Fernando. 2008. "La cuestión del objeto como cuestión sociológica”. In SANCHEZ CRIADO, T. et al. (eds.): Tecnogénesis. La construcción Técnica de las ecologias humanas. pp. 79-112. Madrid: Antropólogos Iberoamericanos en Red.

FISHER, William. 1991. Dualism and its Discontents: Social Process and Village Fissionig Among the Xikrin Kayapo of Central Brasil. Tese de Doutorado. Michigan: UMI.

GELL, Alfred. 1998. Art and Agency. An Anthroplogical Theory. Oxford: Clarendon Press.

GIDDENS, Anthony. 1984. The Constitution of Society: Outline of the Theory of Structuration. Cambridge: Polity Press.

HEIDEGGER, Martin. 1989. El Ser y el Tiempo. México/Madrid/Buenos Aires: Fundo de Cultura Economica.

KOPYTOFF, Igor. 1986. "The Cultural Biography of the Things: Commodization as a Process". In APPADURAI, A. (ed.): The social life of things: commodities in cultural perspective, pp. 64-91. Cambridge: Cambridge University Press.

LATOUR, Bruno. 2005. Reassembling the social. An introduction to Actor-Network Theory. London: Oxford University Press.

LEA, Vanessa. 2012. Riquezas intangiveis de pessoas partiveis: Os Mêbêngôkre (Kayapó) do Brasil Central. São Paulo: Editora da Universidade de São Paulo.

MACHADO E SILVA, Regina C. 2010. "Memórias pessoais de um desencontro em 2000". Travessias, 4(3): 255-257.

MARCHETTI, M. \& NICOLARDI, C. 2007. "La Collezione Etnografica". Thule. Rivista Italiana di Americanistica. Edizione Speciale in occasione del trentesimo anniversario dela fondazione: 55-59.

OLIVEIRA, João P. 2012. "A refundação do Museu Magüta: etnografia de um protagonismo indígena". In MAGALHÃ̃ES, A. \& BEZERRA, R. (eds.): Coleções e colecionadores. A polissemia das práticas, pp. 201-218. Rio de Janeiro: Museu Histórico Nacional.

RIBEIRO, Berta. 1988. Dicionário do artesanato indígena. Belo Horizonte/ Itatiaia/ São Paulo: Editora da Universidade de São Paulo. 
RUSSI, Adriana. 2019. “'Museologia colaborativa': diferentes processos nas relações entre antropólogos, coleções etnográficas e povos indígenas". Horizontes Antropológicos, 25(53):17-46.

SAÏD, Edward. 1978. Orientalism. London: Routledge.

SANTOS-GRANERO, Fernando (ed.). 2009. The Occult Life of Things: Native Amazonian Theories of Materiality and Personhood. Tucson: University of Arizona Press.

SIMONDON, Gilbert. 1989. Du monde d'existence des objects techniques. Paris: Aubier.

TILLEY, Christopher. 2006. Handbook of Material Culture. Thousand Oaks: Sage.

VELTHEM, L. H., KUKAWA, K. \& JOANNY, L. 2017. "Museus, coleções etnográficas e a busca do diálogo intercultural". Boletim do Museu Paraense Emílio Goeldi, 12(3):735-748

\begin{abstract}
This paper describes the Amazonian Amerindians' artefacts included in the Ethnographic Collection of the Centro Studi Americanistici 'Circolo Amerindiano', in Italy. One of the most relevant ethnographic collections devoted to the Amerindian peoples, it possesses a rich ensemble of Amerindian artefacts from all the American continent. Here the artefacts part of the Amazonian section of the Collection will be detailed. The aim of the paper is to show how these artefacts can be observed not as simple inert and passive object, but rather as active subjects of a continuous production of differences redefining other subjects involved in the museum encounters. In this way, these artefacts let an Amerindian agency to emerge, also if the Amerindians are not directly engaged in the expositive trajectory.
\end{abstract}

Keywords: Circolo Amerindiano, Indigenous people, Brazil, Etnographic collections, Objects. 